\title{
Sons e sentidos: entrevista com Steven Feld
}

\author{
Rita de Cácia Oenning da Silva ${ }^{1}$ \\ Universidade Federal de Santa Catarina
}

Steven Feld, músico, fllmmaker e professor de antropologia e música nascido nos Estados Unidos, é um pesquisador que desde o começo de sua carreira desafiou paradigmas, inventando novos modos de perceber e de fazer pesquisa. Músico atuante na cena norte-americana, é um pensador importante para a antropologia, especialmente a dos sentidos. Já no começo da sua carreira como antropólogo, quando aluno de Alan Merriam, propôs uma antropologia do som, se contrapondo à antropologia da música defendida por seu mestre. O termo música pareceu, desde o princípio, muito restritivo para pesquisar e pensar a diversidade de sons e pensamentos que existem no mundo. Perseguiu desde sua entrada na antropologia um termo que representasse o entendimento de como se dá a escuta, e logo a produção sonoro-afetiva e cognitiva de diferentes grupos sociais e o sentido que os grupos dâo a essa produção. Chegou assim à acustemologia, termo que se refere ao mesmo tempo à acústica - fazer e perceber som - e à epistemologia - como se chegar ao saber. O som é uma maneira de conhecer o mundo, um habitus, um mapa onde povos podem se situar física e emocionalmente.

Sua obra mais conhecida mundialmente é a publicação da sua tese de doutorado (Indiana University, 1979) sobre os Kaluli, um povo que mora em Bosavi, Papua Nova Guiné, habitantes da floresta equatorial, trabalho que contribuiu para uma antropologia/etnologia densa daquela 
ENTREVISTA COM STEVEN FELD, POR RITA DE CÁCIA OEENING DA SILVA

regiáo. Sua longa estada entre os Kaluli o levou a desenvolver o debate sobre a acustemologia. Em Sound and Sentiment: Birds, Weeping, Poetics, and Song in Kaluli Expression (1982, segunda edição em 1990 e terceira em 2012, Filadélfia, University of Pennsylvania Press) ${ }^{2}$. Feld traduz as etnoteorias musicais expressas em linguagem metafórica dos Kaluli. Aborda ao mesmo tempo a relação desses com o som, a floresta e as emoçôes. Trabalha, por um lado, com a expressão vocal ritualizada, especialmente cançóes e lamentos de mulheres kaluli nos funerais e, por outro, trata da vida cotidiana, dos cuidados com as crianças - meninos especialmente. O simbolismo de lamentos e cantos está imtimamente conectado com pássaros da floresta, que são entendidos como espíritos, e tais lamentos são entendidos como incorporaçáo da tristeza de se tornar um pássaro. Essa tristeza faz os ouvintes dos cantos chorarem como pássaros, completando um círculo simbólico e emocional que vai da fala para o choro, do choro para a música - tudo refletido no som dos pássaros.

O primeiro contato de Feld com os Kaluli foi pela escuta. Ouvindo as gravações dos Kaluli feitas no trabalho de campo de Edward Schiefelin ${ }^{3}$, se inspirou a estudar esse povo do Bosavi e o fato que Edward e a irmã de Feld, Bambi Schiefelinn ${ }^{4}$, trabalhavam entre os Kaluli desde o ano de 1966 facilitou a chegada de Feld. Bambi e Edward levaram seu filho de cinco anos para o campo em Papua New Guinea e, porque os Kaluli consideram a relaçáo entre o tio materno (Feld, nesse caso) e o sobrinho como sendo especial, Feld teve uma ponte instantânea para a comunidade. Passou a ser "Babo", posição privilegiada nas relaçôes de parentesco dos Kaluli.

Veremos nesta entrevista, que Steven Feld concedeu em seu escritório na Universidade do Novo México em abril de 2012, que essa conexão na entrada do campo auxiliou o pesquisador a estabelecer uma relação diferenciada com o grupo pesquisado; ao invés de se relacionar principalmente com os "especialistas da música", como faziam quase todos 
REVISTA DE ANTROPOLOGIA, SÃO PAULO, USP, $20 \mathrm{I} 5$, V. $58 \mathrm{~N}^{\circ} \mathrm{I}$.

os etnomusicólogos desse período, Feld conviveu cotidianamente com crianças e mulheres, cozinhando, indo pesquisar na floresta com elas, aprendendo sobre sua vida cotidiana e também sobre seus rituais e mitos. Feld destaca na entrevista essa relação com seu sobrinho e com as crianças kaluli como momentos importantíssimos na sua pesquisa de campo. Com eles aprendeu a língua e a importância de ouvir os sons da floresta. É nessa relação intensa e cotidiana com as crianças e seus familiares que pôde desenvolver na sua pesquisa uma teoria que conecta cuidado, produção de pessoa, sentidos e som ouvidos e produzidos pelos Kaluli. Feld acompanhou algumas destas crianças por quase 30 anos, numa relação de amizade e cuidado mútuo.

Além da escrita sobre o grupo, convivendo com esses durante longo tempo, Feld participou da gravação de diversos CDs entre e com os Kaluli ${ }^{5}$, registrando o som em três geraçôes distintas, em momentos também distintos. No entanto, Feld não entende essa produção como um apêndice das suas escritas sobre esse povo. A música e os sons produzidos pelo grupo, bem como sons vindos de suas florestas, formam uma etnografia sonora. Esse é um importante argumento que o autor traz sobre a relação entre a produção sonora e fílmica feita por um etnógrafo e a escrita da tese, de um livro ou artigo. Propóe uma etnografia do som e da imagem, na qual esses registros não verbais são tão válidos quanto livros que abordam a vida de um grupo. Nas suas aulas de antropologia, utiliza essa produção sonora e audiovisual, possibiltando ao estudante ouvir, ver e pensar sobre o modo como grupos ouvem e produzem movimentos e sons ${ }^{6}$.

O complexo debate sobre a produçáo da world music faz parte dessas aulas. Não é somente pensar a produção do som e da imagem que importa, mas como se produz, com quem se produz, como é veiculado, com que fins se produz, quem se apropria desse produzir. $\mathrm{O}$ único texto do autor traduzido para o português é justamente uma reflexão sobre a 
ENTREVISTA COM STEVEN FELD, POR RITA DE CÁCIA OEENING DA SILVA

world music. Trata-se do texto "Uma doce cantiga de ninar para a world music" "', no qual Feld nos apresenta uma reflexão complexa e critica sobre o tema.

Steven Feld não é somente um professor ${ }^{8}$ e um escritor bem-sucedido. Sua produçáo audiovisual e sonora têm se destacado, dando mérito ao seu argumento de que elas falam por si e são fundamentais para escutar um povo. Essa premissa levou Feld a fundar no ano de 2002 a VoxLox label, uma editora cuja a produçáo áudio e visual são elementos centrais. A editora vem lançando trabalhos de diversos artistas, levando a sério a premissa da valorização da produção de som e imagem. Uma das publicaçóes promovidas pela Voxlox, por exemplo, foi a reflexão feita sobre fotografias de negros da África do Sul com a artista plástica Virginia Ryan?. Feld percebeu as que imagens de uma branca rica tirada por negros ao lado de negros de um país colonizado, contituia uma antropologia ao revés - os negros pesquisando uma mulher rica e branca. Trata-se de uma reflexão sobre a inversáo dos papéis (quem pesquisa quem) e do fazer antropológico. VoxLox publica projetos, misturando arte e antropologia como um meio de promover diálogos e estimular nossa sensibilidade.

Para finalizar, ou, melhor dizendo, para iniciar, num momento em que os ruídos acadêmicos e políticos são tantos, parece importante o ouvir, e ouvir alguém que também escuta e se preocupa em pensar essa escuta. No seu escritório na Universidade do Novo México, Feld me recebeu com inteira atençăo, ouvindo minhas perguntas, e concedeu a entrevista abaixo, com a qual muito aprendi. Espero que a publicação da mesma possa divulgar e registrar o belíssimo trabalho que Steven Feld vem produzindo, suas ideias e suas teorias, que, penso, são bastante apropriadas para uma boa antropologia dos sons e dos movimentos, inclusive daqueles que temos feito no nosso país diverso e musical. Escutemos, escutemos! 
REVISTA DE ANTROPOLOGIA, SÃO PAULO, USP, $20 \mathrm{I} 5$, V. $58 \mathrm{~N}^{\circ} \mathrm{I}$.

\section{Sons, sentimentos, ecologia}

Sua obra tem chamado atenção por destacar a música como apenas um dos muitos sons produzidos por determinados grupos e por conectar diferente tipos de som a aspectos importantes da vida, como os sentimentos, os rituais, as atividades do dia a dia, os diferentes espaços, a ecologia, etc. Você faz uma importante distinção do seu trabalho para aquilo que propunha fazer a etnomusicologia do início da sua entrada na antropologia. Você poderia falar um pouco como chegou a uma "antropologia do som" nas suas pesquisas? Melhor dizendo, você poderia falar da forma como ficou desapontado com a etnomusicologia e como e porque "inventou" a abordagem "Echo-Muse-Ecology"lo, e o que significa?

Comecei a estudar etnomusicologia em 1971 na Indiana University com Alan Merriam. Alan era um famoso antropólogo que estudava música, e foi ele quem tornou conhecido o termo "antropologia da música". Ele escreveu em 1964 o livro Antropologia da Música. Nesse livro, tentou juntar as ideias de etnomusicologia, mas sob a perspectiva antropológica. Fazia uma polêmica sobre etnomusicologia ser dominada pela musicologia, sempre dentro de escolas de ou departamentos de música. Era contra a etnomusicologia ser apenas uma disciplina para os musicólogos que estudam a música não-ocidental. Insistiu que os antropólogos tinham muito para contribuir estudando, por exemplo, o comportamento de músicos, conceitos de música, a posição social da música, a perfromance da música, as letras musicais. Ele tinha muitas ideias sobre como estabelecer um contexto social para a música.

Em meu primeiro curso com Alan Merriam - era um seminário da graduação - estávamos lendo o livro dele e tínhamos que escrever um $p a$ per abordando suas ideias. Comecei o texto com a pergunta: "E por que não uma antropologia de som?", como um meio de argumentar sobre a 
ENTREVISTA COM STEVEN FELD, POR RITA DE CÁCIA OEENING DA SILVA

antropologia da música, porque "música" é uma categoria já constituída pela história do Ocidente. Na graduação, eu tinha estudado com Colin Turnbull, um antropólogo que pesquisava a música da mata na África Central, entre um grupo muitas vezes chamado de "pigmeus". Somente escutando as gravaçóes feitas lá, me dei conta que o som do ambiente era muito importante. Tinha uma relaçáo entre os sons da mata e os sons do meio ambiente. Comecei a pensar que uma antropologia de som poderia questionar as relaçôes entre música, linguagem e som do ambiente. Uma antropologia de som poderia fazer perguntas sobre o todo, a importância do som na vida de um grupo de pessoas. Não era a música, canto ou som instrumental que estava me referindo, mas ao jeito como as pessoas escutam. Se você estuda algo como música, tem que fazer ume etnografia da percepção, do escutar, do perceber o mundo acústico. Também existe uma relação entre escutar e fazer som; escutar não é só biológico ou físico ou fisiológico. Escutar é também cultural, e o que a gente decide focar ou não focar na escuta tem uma dimensão cultural.

Entáo, a antropologia do som foi uma resposta a Alan Merriam e seu projeto de uma antropologia de música. A ideia de uma antropologia da música é etnocêntrica, em parte, pois não está aberta às perguntas mais importantes sobre escutar e ouvir como capacidades humanas. Todos escutamos, todos ouvimos, mas o que é que a gente faz com isso? Como isso se relaciona com o mundo físico que habitamos? Com o lugar, o som do ambiente?... Todos nós, seres humanos, sabemos muito do mundo que habitamos só o escutando. Isso não tem nada a ver com a música. Tem a ver com a capacidade de escutar.

Som é importante desse jeito, mas também porque tanto a música quanto a linguagem envolvem o som. Como comparar e juntar essas coisas? Isso também mostra como a antropologia da música é etnocêntrica, porque existem muitas formas de expressão entre linguagem e música que envolvem som. O exemplo perfeito disso é o choro. Chorar é fazer 
REVISTA DE ANTROPOLOGIA, SÃO PAULO, USP, $20 \mathrm{I}$, V. 58 N $\mathrm{N}^{\mathrm{O}} \mathrm{I}$.

som, dar uma forma ao som, mas esta forma é específica à cultura. Ela interage com a linguagem, interage com a música, mas não é só uma nem a outra. Não é canto, nem é música instrumental. Então, penso que o projeto de Merriam náo enfrentava essas coisas que existem entre uma categoria e outra, o que penso que uma antropologia do som pode enfrentar. Mas, além disso, não se enfrenta a questão do som do ambiente, do som ecológico e o conhecimento do mundo que lá se encontra. Eu queria estudar a floresta porque depois da minha experiência na graduação com Turnbull estudando os pigmeus, eu me dei conta de que a mata é um campo rico para pensar essas questóes. Pode-se estudar do ponto de vista da língua, da música, da ecologia, desde a antropologia da voz, emoção e som enquanto parte da antropologia dos sentidos. Para mim, a ideia de uma antropologia do som ligava-se, desde o começo, a uma antropologia dos sentidos.

Um livro que amei, já que estava lendo muita filosofia, era $A$ Fenomenologia da Percepção, de Maurice Merleau-Ponty. Ele influenciou todo meu pensamento sobre uma antropologia do som e dos sentidos. Oferecia uma perspectiva crítica para entender linguagem, música e lugar. Essas questôes e leituras me vieram muito cedo, quando eu era aluno, em 1972.

Isso tudo aflorou como reação aos meus professores, especialmente ao trabalho de Alan Merriam. Eu comecei a trabalhar na Nova Guiné entre 1975 e 1977. Foi lá que desenvolvi a ideia de uma etnografia de som, ou o estudo de som como um sistema cultural. Essa era uma época do declínio de estruturalismo, mas eu ainda estava muito inspirado em estudar com Claude Lévi-Strauss. Então, a perspectiva estruturalista entrava nessa minha abordagem, mas também as perspectivas interpretativas de Geertz e ideias da semiótica e da comunicação. Já no final do livro Sound and Sentiment, a influência da fenomenologia foi maior.

Depois desse livro - acabei em 1979 e foi publicado em 1982 - voltei à Nova Guiné várias vezes entre os anos 80 e 90 . Comecei a pensar que a 
ENTREVISTA COM STEVEN FELD, POR RITA DE CÁCIA OEENING DA SILVA

antropologia de som era um bom conceito, e dava conta do que eu estava fazendo, mas era preciso refiná-lo. Comecei a falar de acustemologia. O termo é o mais importante dessa perspectiva, já que coloca de lado o debate sobre música. Acustemologia junta a palavra acústica - fazer som, perceber som - com epistemologia - conhecimento. Entáo, a ideia era pensar o som como um modo de conhecer, som como um método de conhecimento do mundo, som como um habitus. Escutar como habitus - no sentido usado por Bourdieu -, escutar como prática quotidiana e social de estar no mundo e achar o nosso lugar nele.

A proposta, então, é que o senso de si, os sentidos, a emoção, as práticas corporais, a agência social, que todas essas coisas estão conectadas de algum modo ao som, e que toda agência humana envolve escutar, ouvir e falar. Então, o som é uma capacidade central dos seres humanos, tanto para entender o mundo quanto para agir nele. Estou mais conectado a uma perspectiva que considera o corpo, a história, a fenomenologia, a filosofia, a materialidade do som com uma preocupação com agência e habitus. É um movimento que vai da antropologia do som à acustemologia. Foi assim que essas ideias se desenvolveram.

Comecei com a antropologia como antropólogo que se importava com linguagem e música. Abri essa questão do som para pensar a relação entre linguagem e música, e depois fui para uma questão maior que envolve não somente músicos, e não somente linguística ou habilidade linguística. Daí, foquei uma série de questôes que se conectavam com agência e habitus, e com a antropologia dos sentidos, da emoção, de como habitar um corpo. Queria incorporar todas estas perspectivas.

Agora estou pensando a acustemologia também de outra maneira: como conhecer o mundo não apenas pelo som, mas pela gravação do som. Náo conheço o Brasil, mas tenho escutado muita música brasileira. Não falo português, mas tenho ouvido muitas pessoas falarem a língua. Qual o meu conhecimento do Brasil desde esta escuta? Habito um mundo onde de 
REVISTA DE ANTROPOLOGIA, SÃO PAULO, USP, $20 \mathrm{I}$, V. 58 N $\mathrm{N}^{\mathrm{O}} \mathrm{I}$.

algum modo conheço o Brasil. Sei a diferença entre choro e frevo, mas não conheço os brasileiros. Nunca estive lá. Então, como sei dessas diferenças? De gravaçôes. Conheço o mundo das gravaçôes e também dos músicos que vieram do Brasil e com quem eu posso tocar aqui.

Para mim, isso se relaciona com uma antropologia do cosmopolitismo e da globalização do som. Também da globalização, da gravação, do rádio, do movimento e da circulação do som. Então, acustemologia é também um bom jeito de estudar a circulação de gente e de cultura para estudar globalização e, especialmente, cosmopolitismo. Em outras palavras, é um modo de estudar o ouvir como uma prática social do cosmopolitismo.

Meu último livro é baseado numa pesquisa que fiz na África entre 2004 e 2010: Jazz Cosmopolitanism in Accra. É sobre músicos de jazz de lá que não viajam à América nem trabalham com os músicos daqui, mas conhecem muito sobre nós. Vou à África e conheço a pessoas que estão escutando a mesma música que eu escuto há 40 anos! Instantaneamente nos reconhecemos. Por que sentimos que nos conhecemos há 40 anos? Porque por todo esse tempo estivemos escutando a mesma música e nos envolvemos apaixonadamente com a mesma música. Isso para mim é um tipo peculiar de cosmopolitanismo musical que vem de uma genealogia da escuta, uma biografia social de escutar e experimentar a agência de ouvir o som mundial. É acustemologia em Accra, África Ocidental.

Então, nesse livro eu descrevi o cosmopolitismo musical dessas pessoas com quem trabalhei lá, que eu conheci lá, que é também um tipo de acustemologia; um jeito de conhecer o mundo através do som. Ainda que não vivam no mundo do jazz americano, não tenham viajado até aqui, eles experimentam essa intimidade musical e social pela escuta. Trata-se de uma intimidade social pelo som.

Há 40 anos que comecei a falar da antropologia de som, mas só há 20 que começo a me referir ao meu trabalho como acustemologia. 
ENTREVISTA COM STEVEN FELD, POR RITA DE CÁCIA OEENING DA SILVA

Quais os pensadores que foram mais importantes nesta sua perspectiva?

Bem, certamente tenho uma relação com a linguística, outras vezes com a etnomusicologia, com musicologia e tudo isso. Não os nego, não os condeno, mas penso que o meu trabalho tem outra perspectiva.

Não existem muitos pensadores que têm sido importantes no desenvolvimento dessa perspectiva que venham do mundo da música ou da musicologia. Para mim, a minha experiência de campo foi central: 25 anos de trabalho de campo em Nova Guiné, depois na Europa com os Romani - agora chamados de gypsies -, que são cosmopolitas musicais, depois na África. Então muito disso vem da minha experiência com música e músicos do mundo inteiro por muitos anos.

Muitos dos pensadores que fazem uma antropologia dos sentidos, antropologia do espaço, do corpo, antropologia fenomenológica e filosófica me inspiraram, embora muitos deles nem escrevam diretamente sobre o tema. Michael Jackson, por exemplo, inspira esta perspectiva; Pierre Bourdieu é outro; ou Keith Basso, meu colega aqui no Novo México. Marilyn Strathern no Reino Unido também, e Arjun Appadurai e seu trabalho sobre globalização. Experimento muitas conexôes diferentes. Charlie Keil é tanto antropólogo quanto músico e tenho trabalhado com ele; já escrevemos um livro. Há também artistas, músicos, artistas visuais. A perspectiva vem da mistura de muitos elementos.

Esta pergunta eu faço em nome do Professor Rafael de Meneses Bastos. Hoje há etnomusicologia (e antropologia) em praticamente todos os continentes, em suas próprias linguas e não somente em inglês, francês, alemão, etc. Como você percebe a expansão atual da etnomusicologia (e antropologia) para muito longe dos países de sua incepção hegemônica original? 
REVISTA DE ANTROPOLOGIA, SÃO PAULO, USP, $20 \mathrm{I} 5$, V. 58 No I.

Refiro-me a minha abordagem como "escutar as histórias de escutar": este é meu método. Escuto sobre o que os outros no seu contexto local escutam. Em outras palavras, eu faço o que eu chamo de biografia da escuta ou escuta interbiográfica. Escuto de outras pessoas as histórias sobre escutar. Tento entender o que é ter uma biografia-escuta, qual é a agência de escutar no mundo, qual tipo de saber que isso produz? Como é que a escuta sistemática se conecta a outras capacidades, outra práticas, outras atividades? Com é que a escuta faz parte da agência de um indivíduo?

O mundo que o Ocidente colonizou agora coloniza o Ocidente. Nós vemos não só uma resposta às disciplinas coloniais, mas uma inversão completa. Etnomusicologia é um conceito colonial - e devo dizer que não gosto da palavra. $\mathrm{Na}$ minha opiniáo, é quase racista. A palavra veio nos anos 1950, durante a Guerra Fria. A palavra "etnomusicologia" chegou nos anos 50. Depende da ideia do Ocidente versus não Ocidente. O Ocidente tem musicologia; o não-Ocidente tem etnomusicologia. Etnomusicologia é a música dos outros, musicologia trata dos 400 anos da música europeia, e etnomusicologia de tudo o mais. É louco. Por que seguir com este tipo de coisa?

No começo, tinha um hífen entre etno e musicologia... Suponhamos que você é japonês e estuda a música do Japão. Você é musicólogo ou etnomusicólogo? Ou um brasileiro que estuda música do Brasil: é um musicólogo ou etnomusicólogo? Etnomusicólogo porque Brasil forma parte do etno? Ou musicólogo porque você está estudando a música que está lá? Então, penso que a palavra deve se aposentar. Não tem utilidade porque reinscreve a alteridade e o imaginário do mundo colonial e histórico sobre Ocidente e não-Ocidente, das disciplinas acadêmicas literatura e etnoliteratura, música e etnomúsica, arte e etnoarte.

Gostaria de acabar totalmente com esse negócio de etnomusicologia... Mas considero que uma crítica e o bias colonial dela têm que incluir a relação com a musicologia colonial e eurocêntrica. Por isso é 
ENTREVISTA COM STEVEN FELD, POR RITA DE CÁCIA OEENING DA SILVA

importante que a crítica teórica da etnomusicologia venha de fora dos países colonizadores. Deve vir do Brasil, do Irã, da Turquia, por exemplo.

Meu livro Som e Sentimento foi escrito em inglês, mas foi traduzido, primeiro para o japonês. Achei isso maravilhoso. Adorei. Os colegas lá explicaram que a ideia de uma antropologia de som "é bom ângulo para nós; eem sentido na maneira que a gente escuta e enfrenta a música japonesa”. Eu gosto disso. Depois, foi traduzido para o italiano, um idioma europeu, mas importante que não seja francês ou alemão. Não é um dos idiomas da musicologia. Agora foi traduzido para o farsi e adoro a ideia que etnomusicólogos ou antropólogos do Irã pensam que o livro contribui no seu país. Também turco e russo. Adoro o fato que nunca foi traduzido para o francês ou alemáo e sempre outros idiomas. Penso que se torna útil nas regiōes onde vai nascendo essa crítica. É uma crítica que vem de fora da musicologia europeia.

Penso que Rafael de Menezes Bastos é um estudioso muito importante nesse campo, porque tem um lugar na rede intelectual brasileira, e isso exige duas coisas: teoria antropológica de um lado e a realidade indígena do outro. A natureza da relação entre os povos indígenas e o Estado, como isso forma a situação, a estrutura de conhecimento... Dei-me conta disso quando Rafael deu uma palestra na Universidade do Texas quando eu lecionava lá, mas também porque Tony Seeger tinha me apresentado seus escritos. Outros pesquisadores, que estudam música desde uma perspectiva indígena ou uma cosmologia indígena, também falaram que eu deveria que ler os escritos de Rafael. Também tem a questão da ecologia e cosmologia em música, aspecto que, penso, são importantes tanto para ele quanto para mim. Assim, eu tomo o trabalho do Rafael como o meu: estáo fora do estilo de departamentos de musicologia ou de etnomusicologia. Produzem teoria antropológica da percepção e assim ao invés de se encaixarem num termo, abrem o campo ainda mais. 
REVISTA DE ANTROPOLOGIA, SÃO PAULO, USP, $20 \mathrm{I} 5$, V. 58 No I.

\section{Sons, transformaçóes}

Sua mais longa experiência de campo foi entre os Kaluli, em Bosavi, Nova Guiné. Na segunda edição do seu livro Sound and Sentiment você fala de como sua relação com os Kaluli mudou ao longo do tempo de contato com eles. Pode nos contar como essa transformação aconteceu?

Esta transformação na minha relação com os Kaluli foi resultado de três coisas: eu envelheci, eles envelheceram, e o seu contato com o mundo mudou. Desde que eu comecei a escrever e gravar, tenho grande sentido de responsabilidade sobre como representar e apresentar esta experiência. O mundo deles mudou muito com os missionários, a exploração de minérios, os madeireiros e outras coisas que vêm acontecendo na Nova Guiné. Quando eu cheguei lá, a Nova Guiné tinha recentemente se tornado independente, em 1975. Entáo, meu trabalho se deu nos 25 anos depois dessa independência - um tempo no qual se relacionaram com o Estado, com missionários e com forças transacionais, e eu vivenciei cada um deles. Teve também o contato com pesquisadores, os primeiros que aprenderam o idioma deles, entre os quais me incluo. A nossa relação mudou porque somos mutualmente implicados nessa história de encontros de 25 anos.

Em setembro [de 2012], a Duke University publica a terceira edição do livro, no seu 30 aniversário. Escrevi uma nova introdução na qual trato deste tema, "o antes e o agora" e como as relaçóes mudaram.

Você fala na segunda edição do seu livro, que fez um "dialogic editing" do seu livro com os Kaluli. Quando você voltou a campo com seu livro, como os Kaluli reagiram a ele? Concretamente, como foi feito o "dialogic editing"? Quais aspectos importantes mudaram por causa desse diálogo? 
ENTREVISTA COM STEVEN FELD, POR RITA DE CÁCIA OEENING DA SILVA

Eu fui de volta a Bosavi pela primeira vez depois de escrever o livro em 1982. Depois de cinco anos de ausência - acabei a tese de doutorado em 1979 e comecei a dar aula em 1980. Tive vontade de voltar. Enquanto eu estava lá, o livro foi publicado e uma cópia chegou a mim. O que ia fazer? Lá estava, com pessoas que não lêem nem escrevem, e tinha este livro nas mãos. Eles sabiam que o livro era sobre eles porque tinha fotos deles. Como explicar o livro? Como explicar tentativa de entender a sua subjetividade?

Perguntava-me como explicar para eles que no livro estavam as coisas que eles ensinaram a mim, e que eu tomei todas essas coisas e fiz um livro para explicar aos outros. Vi-me num momento muito peculiar, vivendo algo que nunca tinha imaginado ou previsto. Como conversar sobre isso? Como mostrar um livro que você escreveu sobre eles a um povo que não lê, que não tem livros? Como explicar a interpretação das coisas que eles me explicaram?

Tentei falar com as pessoas sobre isso, e algumas coisas interessantes aconteceram. Algumas pessoas perguntaram: "Quem te falou isso?". E depois falaram entre si: "Quem será que falou isso para ele?”. Todos queriam saber como o conhecimento passou deles para mim. Muito interessante. Estavam escutando as coisas que eu lhes contei, e reconstruindo o diário de campo.

Outra coisa que aconteceu é que eu contei uma história e as pessoas perguntaram: "Por que contou essa história, e não aquela?". Algumas coisas estavam no livro, e outras não. Perguntaram, "Por que contar esta história, e a outra não?”.

Dei-me conta que podia escrever sobre a experiência e fazer uma edição dialógica. Eu estava lendo Bakhtin no momento - nos anos 1980, Bakhtin chegou à antropologia americana com força - e pensando na imaginação dialógica. Li e pensei nas teorias de dialogismo, a relação entre a parte linguística do dialogismo e a parte literária ou cultural, e 
REVISTA DE ANTROPOLOGIA, SÃO PAULO, USP, $20 \mathrm{I} 5$, V. 58 No I.

a ideia de polifonia. Juntei isso com o que estava acontecendo na antropologia literária. Geertz escreveu The Anthropologist as Author nessa época. Estavam na minha mente todas as ideias sobre a antropologia como literatura e a etnografia como representação literária.

Pensei que um jeito superinteressante de responder a isso seria a criação de uma "Revista de Antropologia da Nova Guiné": qual seria o artigo que eles escreveriam sobre o meu livro? Como seria se os Bosavi pudessem fazer essa crítica?

Em 1982, tempo em que isso estava acontecendo, trabalhos como Anthropology as Cultural Critique, de George Marcus e Michael Fisher, e Writing Culture, de George Marcus e James Clifford, também estavam surgindo. Também se iniciou a revista "Cultural Anthropology", uma revista experimental e diferente, com George Marcus como editor. Ele estava dando aula em Universidade de Rice e eu na Universidade do Texas, em Austin. São lugares próximos, a só 3 horas de distância. A gente se conheceu e ele pediu que eu escrevesse um artigo para a revista. Eu escrevi sobre esta experiência de fazer "edição dialógica", sobre como os Kaluli interpretaram Sound and Sentiment, como uma contribuição a esta diálogo sobre "writing culture".

A primeira edição de Sound and Sentiment tinha vendido muitas cópias e a Universidade da Pensilvânia queria publicar a segunda edição. Expliquei para eles que queria incluir o ensaio sobre como os Kaluli interpretaram o livro como um posfácio. Eu já tinha voltado duas vezes para Bosavi e incorporei tudo isso. Sound and Sentiment traz o trabalho de campo nos 1970, e o posfácio do campo nos anos 1980. A segunda edição do livro saiu em 1990.

Fiz essa edição dialógica de diferentes maneiras. De vez em quando, sentava com o livro, traduzia o texto e as pessoas respondiam. Outras vezes, tomava um gravador como o teu, dava para alguém e dizia: "A gente já falou disso. Quer levar esta gravador à maloca e falar com 
ENTREVISTA COM STEVEN FELD, POR RITA DE CÁCIA OEENING DA SILVA

o pessoal? Traz pra mim amanhâ”. Desse jeito eu tinha a gravação, mas não estive lá quando as pessoas estavam falando.

Tinha algo especialmente interessante ou inesperado?

Sim, por exemplo, foi a primeira vez que escutei a "Quem foi que lhe contou isso?”. Dei-me conta que tinha uma questão de autoridade: quem tem o direito de falar do assunto?

\section{Você sentiu que se colocou numa situação difícil?}

Foi uma situação experimental. Eu queria entender o que siginficaria uma edição dialógica e o seu uso. A segunda edição tinha esse espírito de experiência científica. Era um momento quando os antropólogos estavam tentando abrir, questionar a autoridade do etnógrafo. Todos tínhamos lido o artigo de James Clifford sobre a autoridade etnográfica, e estávamos tentando achar jeitos de prestar contas - ao menos um pouco - a esse problema. Por isso que a ideia de fazer uma revista onde pessoas que náo lêem falem de livros escritos sobre elas era interessante.

Como a tecnologia dos anos 70 ajudou você em campo e como a tecnologia disponivel atualmente modificou esse campo?

Quando fui à Nova Guiné nos anos 1970, carreguei uma gravadora de fita que pesava 12 quilos. Tinha uma alça que enredava o corpo para carregá-la. Era uma gravadora Nagra, reel-to-reel, e na velocidade de mais qualidade só podia gravar de 15 a 30 minutos. Podia gravar em altíssima qualidade, mas era imenso, e, para gravar no campo, eu tinha que carregar no corpo com uma mala especial ou tinha que empregar alguém para carregar. Eu colocava a mala especial num saco, o saco nas costas 
REVISTA DE ANTROPOLOGIA, SÃO PAULO, USP, $20 \mathrm{I}$, V. 58 N $\mathrm{N}^{\mathrm{O}} \mathrm{I}$.

e depois os microfones. E o mato, como você bem sabe, é danoso para equipamento eletrônico e microfones. Tudo tinha que estar embrulhado em muitas sacolas plásticas com sílica para manter seco. Trabalho de campo era camping e esforço físico.

Depois disso, teve a gravação DAT, seguinda da gravadora em hard disk, que usei na África. No meu trabalho na África, usei os mesmos microfones que usei na Nova Guiné nos anos 1970, microfones que eu amo. Já foram reconstituídos e são maravilhosos, microfones de AKG.

Agora, na África Oeste, eu podia gravar tudo com esta caneta digital. Sempre informei as pessoas antes, mas está aqui no bolso da camisa. Sempre gravo. Depois, à noite, eu tiro a gravação e passo para o iTunes, depois faço a transcrição. Assim sempre tenho arquivos do que as pessoas falam. Parece só uma boa caneta, mas tem um gravador. Tudo é muito mais simples agora.

\section{Crianças e antropologia}

As crianças neste momento dos estudos antropológicos têm sido alvo de atenção mais que em outros momentos da história da antropologia. Você descreve $e$ analisa o mito de um menino que se transforma em pássaro porque se sentiu abandonado quando a irmã mais velha se negou a alimentá-lo ("The boy who became a Muni Bird"), e parece que foi esse mito que atraiu você a pensar a relação dos Kaluli com pássaros, valores sociais e o processo de produção de som (soundmaking). Achei muito interessante o modo como você analisa tal mito, descrevendo como os Kaluli entendem e vivem relaçóes de parentesco, de irmandade, da distribuição de comida, incluindo diferenças entre gêneros. Também é desse mito e dos lamentos cantados nele que você extrai em primeiro lugar, o fato que os Kaluli associam sons a sentimentos. Sendo você irmão de Bambi Schieffelin, autora do livro The Give and Take 
ENTREVISTA COM STEVEN FELD, POR RITA DE CÁCIA OEENING DA SILVA

of Everyday Life: Socialization of Kaluli Children, e tendo ido a campo com ela, poderia falar um pouco do papel das crianças kaluli na pesquisa de Bambi e na sua própria pesquisa?

A experiência de fazer campo em Bosavi sempre foi mediada profundamente pela experiência de estar com as crianças. Quando cheguei a Bosavi, Bambi, seu esposo, e seu filho já estavam lá há 10 meses. $\mathrm{O}$ menino tinha cinco anos e já falava o idioma muito bem. Eu não falava nada. Tínhamos uma relaçáo especial, porque entre os Kaluli, o irmáo da mãe e o filho da irmã tem uma relação especial, e nos chamávamos mutualmente pelo mesmo termo: Babo. Zachary era meu Babo, e eu o Babo dele. Eu era o irmão da máe dele, e ele o filho da minha irmá. Ele foi a minha entrada à comunidade, e eu ficava muito tempo com ele.

Estive com muitas outras crianças também, e segui trabalhando com eles por toda a vida. Eram os filhos e netos dos adultos com os quais estava trabalhando. Agora essas pessoas têm 35, 40 anos, e eu os conheço desde que eram bebês e criancinhas. Tenho uma longa história com eles, mais que tudo graças a Zachary, porque eles eram os amigos de infância dele.

Nos CDs do projeto Bosavi, tem gravaçóes de duas ou três geraçóes. Em 2000, a última vez que estive lá, muitas das pessoas que gravei tinham 30 anos; eu vou lá há 25 anos; entáo, as conheço por toda a vida. É uma parte especial do campo. Tem um sujeito com quem eu conversa muito ao telefone. Agora ele tem 40 anos. O seu pai dele me ensinou a tocar tambor, e seu avô outras coisas. É um privilégio conhecer três geraçôes no transcurso do tempo. Conheci esse homem quando ele tinha oito anos, e o acompanhei por todas as fases da vida. Tenho ajudado eles com escola, educação, outras coisas na vida.

A parte da família (a minha própria) é um elemento interessante do campo. Eu era único porque era irmão da Bambi, que já tinha estado lá em 1966, e voltou dez anos depois fazendo trabalho de campo. Como 
REVISTA DE ANTROPOLOGIA, SÃO PAULO, USP, $20 \mathrm{I} 5$, V. 58 No I.

eu, ela estava fazendo a pesquisa de doutorado. Ela é linguista e tínhamos muito para conversar sobre o trabalho. Também, ela e eu gostamos de cozinhar, e passávamos o dia cozinhando com os Bosavi... Isso quer dizer que ficávamos muito junto das crianças. Ela trabalha com crianças, sobre o desenvolvimento da linguagem na prática de socialização. Por isso, tive mais sorte que a maioria de antropólogos: fui exposto às crianças como carregadores de cultura e como parte da matéria cultural da vida quotidiana, mas também estive ao lado de uma antropóloga que estuda crianças. Seu esposo estudava adultos e ritual, sociedade e estrutura simbólicas. Trabalhava com os mais velhos, no final das suas vidas; pessoas nos 50, 60, 70, 80. Mas ela estava trabalhando com os mais novos, vendo como é que eles acediam à linguagem. Estava trabalhando com crianças de 18, 20 meses de idade, e tinha um ano e meio de trabalho com eles.

Eu conheci todas as crianças que estão no seu livro porque suas mães chegavam à nossa casa todos os dias. Bambi trabalhava com elas em casa ou ia onde elas estavam. Eu a acompanhava às vezes para gravar as famílias falando. Participei no trabalho dela e acessei também o saber que estava buscando, e a cada noite, durante o jantar, falávamos sobre o dia. Foi uma experiência única para mim como pesquisador de campo.

Bambi e Edward sabiam o idioma melhor que eu; tinham chegado antes. Ele tinha estado lá por dois anos nos 1960, e ela por um ano e depois mais 10 meses nos anos de 1970. Eles tinham tanto conhecimento do lugar que a minha vida era muito mais fácil em campo.

É interessante que você gravou a vida quotidiana nessa época. Os antropólogos não estavam tão interessados nisso, mas parece que você sim.

Sim. Para mim, era muito claro que tinha uma conexão entre o som do trabalho, o som da brincadeira e o som quotidiano com todo e qualquer ritual ou cerimônia. Os etnomusicólogos iriam lá só para gravar os 
ENTREVISTA COM STEVEN FELD, POR RITA DE CÁCIA OEENING DA SILVA

cantos e os rituais. Eu me dei conta que se ia fazer uma antropologia de som, eu tinha que atentar para os sons do mato, as trilhas e os mapas da floresta. Entáo, eu tinha que saber muito sobre a ecologia e o sentido de lugar para poder entender essa poesia. Para isso, tinha que sair com as pessoas. Quando se está no mato com as pessoas, você tem que escutar o que elas escutam, escutar e ver o que eles estão ouvindo e vendo.

Então, me dei conta que os cantos são em si uma parte da história de escutar. Um canto pode ser a trilha de um pássaro por um riacho, e as letras mostram como chegar de lá para cá, como uma série de nomes de lugares, e se a passagem do riacho é também passagem do pássaro... E se o pássaro é um antepassado e não apenas uma ave... Você tem que juntar a cosmologia, a ecologia e o som para começar a entender a poesia, ou para entender o canto. Uma aproximação musicológica diria: "Tais notas, tais ritmos, tal idioma, tal letra...”, transcreve e traduz. É como dizer: "Eu quero caminhar até lá, mas primeiro vou amputar a minha perna". Isso é a aproximação da musicologia: "queremos entender esta música indígena, mas primeiro vamos amputar a perna e o ouvido".

Este processo de tentar entender tudo por meio do som tem um papel muito importante para as crianças e para a vida quotidiana. A outra parte da história relacionada às crianças é quando eu vi o amor aos pássaros que eles tinham. Eu queria ir todos os dias ao mato para escutá-los, de manhã e ao pôr do sol. Todas as tardes, pegava o equipamento e ia a algum lugar, se pudesse. Mas as pessoas não te deixam ir sozinho. Assim, as crianças juntavam-se em frente de casa, porque sabiam que eu ia dar comida ou sal, ou bolinhas de gude ou anzóis em troca da sua ajuda.

Então, quando eu ia gravar os pássaros, as crianças iam comigo. Crianças de 10,11, 12 anos. Isso era fantástico. Ia para o mato, escutava um pássaro e ligava a máquina. Tinha sempre um microfone parabólico para gravar à distância e o levantava assim [levanta e aponta com a mão]. As crianças morriam de rir. A minha máo apontava para um lado e eles 
REVISTA DE ANTROPOLOGIA, SÃO PAULO, USP, $20 \mathrm{I} 5$, V. 58 No I.

me agarravam e a puxavam para o outro, e de repente o canto pássaro estava no meu ouvido.

Como sabiam? Eles não viam nada, como sabiam onde estava o pássaro no mato? Sabiam se era pássaro de chão, ou se voava de cá pra lá. Para mim, era um exemplo fantástico de conhecer o mundo através do som. Conhecer por som antes de poder ver. Já com 10, 11, 12 anos, aquelas crianças tinham uma história de escuta fantástica. A sua escuta se desenvolvia com uma nitidez extraordinária, porque assim aprendiam a caçar, a saber o que traz perigo e o que não.

Os pais ficavam tranquilos que eu fosse para o mato com as crianças. Sabiam que as crianças conheciam a trilha sem problemas. Não se perderiam. Se existisse perigo, as crianças cuidariam de mim, e me trariam de volta. Nessa idade, elas já sabiam de tudo isso. Sempre havia crianças comigo e foram elas que me apresentaram ao mundo. Foram as crianças que me ensinaram a liçáo de escuta como habitus. Podiam localizar cada som que escutavam, e podiam me dizer o nome do pássaro. Sabiam qual era o alimento de cada pássaro em cada estação do ano. Tinha esse saber do seu mundo. Já com essa idade era claro que eles eram mestres no seu ambiente. Essa foi a coisa mais importante que eu aprendi, e tanto de crianças como de adultos. Essa é a história mais importante que posso contar a você sobre as crianças, e como elas tiveram um tremendo impacto na minha formação como etnógrafo e na minha tentativa de teorizar essa ideia de escuta como habitus.

Na coletânia Bosavi: Rainforest Music from Papua New Guinea, você registra sons entre os Kaluli em diferentes momentos da vida deles. Vocêpoderia falar do modo como esses três discos expressam a vida e a cosmologia kaluli?

O primeiro dos três CDs, um disco das bandas de guitarra dos anos 1990, é a gravação da música de pessoas que eram crianças e bebês nos 
ENTREVISTA COM STEVEN FELD, POR RITA DE CÁCIA OEENING DA SILVA

anos 1970. Era a primeira geraçáo que tocou guitarra e inventou uma nova música. O segundo disco são os sons e cantos da vida quotidiana, pessoas cantando com os pássaros, com os insetos, com a água. Neste segundo $\mathrm{CD}$ escutamos os sons do mato e a sua relação com todos os sons do ambiente, a fala, a música. Depois, no terceiro CD se escutam nos rituais e cerimônias.

Cada disco conta uma história diferente, mas todos estão ligados, mostrando a conexáo dos sons, formando um triângulo com cosmologia e ecologia. Som, cosmologia, ecologia: eu o chamo do triângulo acustemológico. Nos anos 1990, com as bandas de guitarra, apareceu a ideia que os jovens tinham sua própria música, conectada com a maneira que viviam o mundo; mas a sua relaçáo com a paisagem não era igual a dos seus pais e avôs. Ainda assim, mostravam sua relação com a cosmologia. Quando cantam sobre os pássaros, cantam sobre os seus pais e avôs, pessoas que eu conheço - e estáo colocando suas vozes no canto.

Nos cantos da vida cotidiana, se pode escutar o jeito que água, insetos e pássaros formam o som do meio ambiente. No CD há pessoas cortando árvores e fazendo hortas, as mulheres cozinhando, e se escuta todos esses sons do ambiente onde estáo. Ecologia e a vida quotidiana se integram. Nas gravaçóes de ritual se escuta o pranto ritual, os cantos que viram choro, cada gênero cerimonial do canto. E também se escuta como os cantos são as trilhas rituais pelo mato. Os cantos fazem com que as pessoas chorem, porque sabem qual antepassado, qual parente, se movimenta como um pássaro pelo mato.

Nesta coleçáo Bosavi, a ideia era fazer uma antropologia de som em som. É o equivalente ao acústico de uma etnografia: os três CDs teorizam uma relação de geraçôes, de homens com mulheres, de pessoas com economia e lugar, de cosmologia e som, de cada coisa sobre a vida ritual, mudança social, transformação. Cada coisa que posso dizer sobre os Kaluli, também está exposto em som. 
REVISTA DE ANTROPOLOGIA, SÃO PAULO, USP, $20 \mathrm{I} 5$, V. 58 No I.

Arrumei os CDs de forma experimental porque queria que fosse uma provocação. Queria mostrar para os antropólogos que é possível apresentar uma etnografia em termos puramente acústicos. Não só faço uma antropologia do som para estudar o som como um antropólogo, mas faço uma antropologia $\mathrm{em}$ som. Som é o meio para apresentar a pesquisa.

Espero que as gravaçôes acabem com a ideia que existe uma divisão entre música e natureza, ou entre meio ambiente e vida. As pessoas são o ambiente, e o ambiente é as pessoas. Não é só uma hipótese estruturalista que os pássaros fazem mediações entre as pessoas e o meio ambiente. Essas coisas formam um todo, tudo é uma só coisa. É isso que se consegue escutar.

O som é um meio muito importante porque permite que as pessoas escutem a minha história de escuta nesse lugar. Você escuta o que eu escutei. E porque escuta o que eu escutei, pode fazer perguntas, ou criticar, ou analisar.

\section{Ou sentir.}

É. Às vezes, quando dou aula sobre Bosavi, não mando os alunos lerem nada. Só peço que eles escutem os três discos junto com Voices of Rainforest e Rainforest of Soundwalks, que mostra os sons do mato, do caminhar pelo mato. Começo com o Soundwalks, depois vamos para o Voices of Rainforest, e depois ouvimos os três discos de Bosavi. Nos cinco CDs há cinco horas de escuta. Eu tento ensinar tudo, fazendo com que eles escutem o que eu escutei.

Aqui entramos de volta com a ideia de som como jeito de saber, conhecer o mundo. Estou estudando, isso mas também estou fazendo. Como professor, estou muito interessado em ver como os alunos podem conhecer um lugar quando o escutam. 
ENTREVISTA COM STEVEN FELD, POR RITA DE CÁCIA OEENING DA SILVA

Entre alguns pesquisadores há uma preocupação em localizar suas abordagens enquanto "estruturalistas" ou "bermenêuticas". Seu trabalho entre os Kaluli faz uso das duas maneiras de fazer e entender antropologia, sem a preocupação em se posicionar a favor de uma em detrimento da outra. Ao contrário, você defende a importância de integrar os estudos de como simbolos são logicamente conectados com o estudo de como eles são formulados e performados na experiência cultural. Você poderia falar um pouco sobre isso, e como aproveitou do trabalho de Dell Hymes para integrar no seu trabalho o "estruturalismo" e a "hermenêutica", supostamente dicotômicos para muitos antropólogos?

Sound and Sentiment foi um livro muito difícil de escrever. Eu queria reconhecer a influência de muitos tipos de teorias, dizer que não existe uma teoria que serve para tudo. Estive feliz em ser eclético, misturar tudo, pedir empréstimos de muitas teorias. Talvez devesse ter emprestado mais. Não acho que a teoria pode explicar tudo. Cada teoria é parcial. Tem que ser como Claude Lévi-Strauss, um bricoleur, tomando um pouco de tudo. Pratico a bricolagem teórica e levo a sério todas as teorias, mas não sinto a necessidade ou desejo de me identificar com uma teoria em particular.

O único trabalho seu traduzido e publicado em português é "Uma doce cantiga de ninar para a 'world music", no qual você fala sobre a world music e seu embates. Você acaba de publicar mais um artigo sobre o tema no livro Music and Globalization: Critical Encounters, editado por Bob W. White ${ }^{I I}$. Poderia nos falar um pouco sobre o tema da world music?

Comecei a estudar essa coisa de world music nos anos 1980. Já na metade dessa década, percebi como era importante para um antropólogo estudar a globalização da música e de sua gravaçaáo. Na Nova Guiné, eu trabalhei 
REVISTA DE ANTROPOLOGIA, SÃO PAULO, USP, $20 \mathrm{I}$, V. 58 N $\mathrm{N}^{\mathrm{O}} \mathrm{I}$.

com duas mil pessoas em 250 hectares de terra. Era em parte uma antropologia do exótico. Mas também eu tinha interesse na antropologia do não-exótico, da loja de discos e da rádio: a antropologia de como a música circula.

No final do ano de 1986, foi lançado o disco Graceland, de Paul Simon, no qual Paul toca com músicos da África do Sul. Em termos de relaçóes de poder, essa era uma colaboração complicada. Na mesma época, Arjun Appadurai e sua esposa, Carol Breckenridge, tinham justamente lançado a revista Public Culture na Universidade da Pensilvânia, e eu tinha dado aula lá com eles. Arjun perguntou se eu podia escrever um artigo para o primeiro número da revista, e escrevi um texto sobre Graceland e como o disco conta a história da globalização da música. Foi publicado em 1987 como "Notes on World Beat".

Desde então, fiquei interessado na questão da globalização da música, tentando estudá-la desde a perspectiva política e ética, a mecânica da circulação da música, das relaçóes entre os indígenas e os estrelas, e a indústria da música.

A globalização da música conta-nos, por um lado, uma história de esperança: a possibilidade de mais respeito, novas formas de validação. Dá para ver a capacidade que a música tem para chamar a atenção para a diferença cultural, para as culturas mais remotas no mundo; e isto pode ser base de reconhecimento político. É uma história muito positiva e me interessa pesquisar.

Por outro lado, a história que não é tão positiva. Nessa história, música não é diferente de mineração. Aqui, temos um povo com um recurso: como podemos aproveitar dele? $\mathrm{O}$ recurso da música de um povo pode ser explorado do mesmo jeito que petróleo, ouro, ou seja lá o que for.

Para mim a pergunta sobre world music é: como contar as duas histórias ao mesmo tempo? Como contar a história da possibilidade e da 
ENTREVISTA COM STEVEN FELD, POR RITA DE CÁCIA OEENING DA SILVA

esperança, da exploração e da ansiedade, em estéreo? World music produz as duas coisas na mesma hora, e pelo mesmo mecanismo.

O artigo "A Sweet Lullaby for World Music" enfrenta este desafio pensando as duas palavras - "ansiedade" e "celebração" - como os dois tropos da world music, completamente enredados. Esta é a minha perspectiva. É uma perspectiva que está relacioada com os dois discursos da world music e as práticas atuais de como a música circula, ou não circula. Este é um trabalho que acontece em paralelo ao meu trabalho etnográfico.

Você poderia falar do modo como você concebe (e realiza) CDs e DVDs - traduzidos por sons e imagens - como importantes argumentos numa pesquisa, afirmando que é preciso também ouvir e ver, e não somente escrever sobre um grupo? Desse modo, você poderia falar dos seus trabalhos mais atuais, acredito que pouco conhecidos no Brasil, como The Time of Bells, Suikinkutsu: A Japanese Underground Water Zither, 2006; The Castaways Project, Topographies of The Dark, trabalhos esses que focam nesse seu argumento estético?

Um luxo que eu tenho é que já escrevi livros, e fiz o que um antropólogo deveria fazer com o texto escrito. Isso me dá a licença de, nestes últimos anos, produzir DVDs e CDs. Há dez anos decidi que ia passar uma década publicando em grande parte em som e vídeo. Seguiria publicando artigos - e semana passada publiquei um novo livro - mas estou gostando muito de produzir em forma de vídeo e som.

O problema é o seguinte: não posso dar este conselho aos meus alunos. Não podem passar em concursos e não podem chegar a ser professores fazendo CDs e DVDs. Mas eu tenho este luxo, e sou persistente e agressivo quando as pessoas perguntam: "E o que você está fazendo agora?" Eu digo, "Eis o CD que acabo de publicar. Escuta aî". Por dez anos, publiquei a cada ano dois CDs. É muito trabalho e cada 
REVISTA DE ANTROPOLOGIA, SÃO PAULO, USP, $20 \mathrm{I} 5$, V. 58 No I.

CD é diferente. Assim, publiquei $20 \mathrm{CDs}$, e os vejo como um mapa de 20 diferentes maneiras de fazer antropologia do som. Estuda em som, apresenta em som - e em alguns casos também com vídeo.

Mas agora voltei a escrever livros e gosto de escrever. Ainda tem alguns livros que gostaria de escrever. O meu livro Jazz in Accra acaba de sair e em setembro de 2012 sairá a terceira edição de Sound and Sentiment. Agora estou trabalhando em um livro que vai relatar todo o meu pensamento sobre a world music. A ideia é fazer um livro que passa por 30 anos de escritos sobre world music, música mediada, e a experiência com produção de rádio e TV.

A internet possibilita isto agora. Vi o seu site e achei muito bom. Os antropólogos deveriam fazer mais disso, trabalhar mais com tecnologia. É importante que antropólogos usem internet para divulgar seus vídeos, fazer com que outros topem com eles, com o som, com a pesquisa. Basicamente, cada gravação, filme, ou CD mostra um aspecto diferente de som como jeito de saber. Em alguns casos sou performer. Outras vezes, o produtor. Todos esses trabalhos abordam de modos variados a música. Alguns são documentários, outros composiçôes, outros performances. Todos trabalham com som. Alguns têm a ver com rádio, outros com filme. Estou tentando produzir várias coisas diferentes.

Falando da editora VoxLox, eu queria publicar gravaçóes e percebi que se tivesse que pedir a editoras a cada novo projeto, ia me limitar. Tinha que passar muito tempo e fazer muito esforço para convencer um editorial a publicar as coisas. Pensei: vou fundar uma editora, uma empresa de produção, e faço eu mesmo. Isso é a VoxLox. Começamos em 2003 e já publicamos uns 19 projetos. É um milagre que tenhamos conseguido financiar tantos projetos. Agora vou um pouco mais devagar.

Também publicamos CDs, DVDs com CDs, livros, e livros com CDs e DVDs. Estou trabalhando em outro livro e a ideia é fazer colaboraçôes entre artistas e antropólogos. O livro é sobre Virginia Ryan, artista 
ENTREVISTA COM STEVEN FELD, POR RITA DE CÁCIA OEENING DA SILVA

plástica. Neste caso, é sobre as representações de ser branco no Oeste da África. Outro projeto entre nós é ela como artista e eu como músico. Também colaborei com um fotógrafo e dois antropólogos gregos, um livro sobre carnaval na Grécia. Cada projeto é um tipo de experiência, de encontros entre arte e antropologia. Alguns projetos da VoxLox sáo políticos, e tem relação com direitos humanos. Em outros casos, tem a ver com a ecologia acústica. Cada um é uma experiência diferente. Um CD é Música do Iraque em Época de Guerra, com um refugiado iraquiano, um músico. O projeto Iraqnophobia é um projeto político.

Alguns desses projetos são com amigos, outros são de pessoas que se aproximam e querem produzir junto. Quando estava na África, uma fotógrafa me mostrou algumas fotos dela com africanos, fotos feitas pelos africanos, e eu disse: "Isso é um tipo de antropologia em reverso. Você permite ser vista como branca e rica". Ela me disse, "Sou artista, e é interessante que as pessoas me olhem por ser tão branca. Dei a câmara a elas, e perguntei se queriam tomar fotos. Queria ver o que aconteceria”. É uma antropologia ingênua, invertida, e comecei a olhar as fotos com ela, tinha tantas! Propus que fizéssemos uma seleção, que achei muito provocativa. Eu disse: "Vamos publicar isso junto. Eu escreverei um ensaio sobre raça e branquitude na África pós-colonial”.

[Mostra uma foto]. Esta foto é de uma mulher que trabalha em uma embaixada com seus guarda-costas. Levanta uma série de questóes sobre raça e poder. Eu queria escrever sobre elas como um tipo de desafio à antropologia visual. Ou fotos dela com crianças no sol, onde ela parece ainda mais branca. Ela fica mais branca, eles mais pretos.

Ela é artista visual, muito sensível a essas coisas como documentos ou formas visuais. Interessou-me como um tipo de material ou documento cultural. Esta foto, por exemplo: ela no saláo de beleza com nome "Beleza Negra". Ela, táo branca, e uma negra arrumando o cabelo dela. A foto tem todo um ensaio sobre raça; é muito político isso. Brancos 
REVISTA DE ANTROPOLOGIA, SÃO PAULO, USP, $20 \mathrm{I}$, V. 58 N $\mathrm{N}^{\mathrm{O}} \mathrm{I}$.

sempre tomam fotos dos negros, mas o que acontece quando se inverte? Quando o branco é objeto das fotos feitas pelos negros? Quando a vida quotidiana dos brancos é exposta? A sua vida de poder, riqueza e prestígio fotografada por alguém que náo tem essa coisas.

Os projetos da VoxLox são visuais e acústicos. Livros, CDs, DVDs, colaboraçôes entre artistas e antropólogos. Alguns projetos são políticos, outros experimentais. Alguns são documentários. Muitas coisas. Você pode encontrá-los no www.voxlox.net.

Muito obrigada pela sua disposição, Steve. Aprendi muito hoje.

Foi um prazer.

\section{Notas}

1 Pós-doutoranda Ppgas/ufsc (Bolsa PDj CNPq) e pesquisadora do musa Ppgas/ufsc.

2 Na segunda edição, o autor agrega uma importante reflexão sobre ouvir os Kaluli falarem sobre o livro. Faz uma edição coletiva da sua obra (co-editing), na qual abre a obra a críticas e modificaçóes sugeridas pelo grupo. Já na última edição aponta as mudanças na região da pesquisa desde 1976 por conta dos contatos e das missóes.

3 Edward L. Schieffelin formou-se em antropologia pela Universidade de Chicago. Entre 1966 e 1968 estudou os Kaluli do Grande Platô da Nova Guiné, Papua Nova Guiné. Sua pesquisa sobre a cerimonia de iniciação dos Kaluli, o gisalo, resultou no livro Sorrow of the lonely and the burning of the dancers. New York: St. Martin's Press, 1976. Escreveu ainda, juntamente com Robert Crittenden, o livro Like People You See in a Dream: First Contact in Six Papuan Societies. Redwood City/CA, Stanford University Press, 1991.

4 Bambi B Schieffelin é uma antropóloga que trabalha com linguística e leciona no departamento de Antropologia da Universidade de Nova York. Sua obra mais conhecida é The Give and Take of Everyday Life: Language Socialization of Kaluli Children. Cambridge: Cambridge University Press, 1990. Tem escrito extensivamente sobre linguagem e socialização, ideologia e linguagem, contato e criolização.

$$
-467-
$$


ENTREVISTA COM STEVEN FELD, POR RITA DE CÁCIA OEENING DA SILVA

5 Music of the Kaluli. Institute of Papua New Guinea Studies, 1981; The Kaluli of Papua Nugini: Weeping and Song. Bärenreiter Musicaphon, 1985; Voices of the Rainforest. Rykodisc, 1991; Rainforest Soundwalks: Ambiences of Bosavi, Papua New Guinea. Earth Ear, 2001; Bosavi: Rainforest Music from Papua New Guinea. Smithsonian Folkways, 2001.

6 Sons, cantos e imagens formaram o material de estudo das aulas que assisti com Steven Feld na Universidade do Novo México, no Departamento de Antropologia, por ocasião do doutorado sanduíche que fiz naquela instituição em 2005, sob orientação da professora Suzanne Oakdale (UNM/USA).

7 Feld, Steven. 2005. "Uma doce cantiga de ninar para a 'world music". Debates, Rio de Janeiro, Unirio, n. 8: 9-38.

8 Desde 2003 Steven Feld é Distinguished Professor de Antropologia e Música na University of New Mexico. É professor visitante no departamento de Anthropology and Folklore Program at UC Berkeley em 2012. Trabalhou em diversas universidades conhecidas dos Estados Unidos, como Columbia University, New York University, University of California de Santa Cruz, Santa Cruz, Universidade de Texas, Austin, Universidade de Pensilvania. Desde 2001 mantem uma conexão com Grieg Academy, University of Bergen, Norway.

9 Acessar o link http://voxlox.myshopify.com/collections/all para conhecer os trabalhos publicados pela VoxLoX.

10 Steven Feld. "Essays From Ethnomusicology to Echo-Muse-Ecology: Reading R. Murray Schafer in the Papua New Guinea Rainforest.” The Soundscape Newsletter, Number 08, june, 1994. Disponível em http://www.acousticecology.org/writings/ echomuseecology.html.

11 Feld, Steven. "My life in the bush of ghosts. 'World Music' and the Commodification of Religious Experience". In White, Bob W. (org.), Music and Globalization: Critical Encounters. Bloomington, Indiana University Press, 2012. 